Biochem. Lett., Vol. 5, PP. 106-112 (2009)

\title{
INHIBITION BY GLUCOCORTICOIDS OF PIT 1 INDUCED ACTIVATION OF TRANSCRIPTION FROM RPR1 PROMOTER FRAGMENTS IN NON PITUITARY CELLS
}

\author{
S. Eljaafari, A:B. El-Fighi and I.M.fahelbum \\ Department of biochemistry faculty of medicine \\ Alfateh University
}

\begin{abstract}
ABSRACT
Bovine and rat prolactin gene promoter function by glucocorticoids. It was of interest, therefore to examine the possible inhibition by glucocorticoids of pit $l$ induced activation of transcription from the 3'- rPrl promoter mutant generated for this study. The studies were carried out by co-transfection into glucocorticoids receptor (GR) deficient $C V-1$ cells both pin1 and (GR) expression vectors and the reporter CAT plasmids with upstream rPrl promoter fragments. The effect of glucocorticoids was examined by the Addition of dexamethasone $(10-6 \mathrm{M})$ to the cultures immediately after transfection. In these studies glucocorticoids receptor (GR) deficient $C V$-l cells were used and the (GR) was expressed from an expression vector parker et al. (1994). However, in the case of prolactin promoter fragments (eg, - 1960/+ 38, -44/ -423, -190/-423 and -75 $1+38)$ decreased in pitl induced $D A T$ gene expression was seen when the (GR) was expressed but it was evident even in the absence of glucocorticoids.
\end{abstract}




\section{INTRODUCTION}

Comper et al. (2) and Adler et al. (1) clearly demonstrated the inhibition. Bovine and rat prolactin gene promoter function by glucocorticoids. It was of interest, therefore to examine the possible inhibition by glucocorticoids of pit 1 induced activation of transcription from the $3^{\prime}-\mathrm{rPrl}$ promoter mutant generated for this study.

As illustrated in (Figure1) the studies were carried out by cotransfection into glucocorticoids receptor (GR) deficient CV-1 cells both pin 1 and (GR) expression vectors and the reporter CAT plasmids with upstream rPrl promoter fragments. Treacy et al. (1988).

The effect of glucocorticoids was examined by the Addition of dexamethasone (10-6 $\mathrm{M})$ to the cultures immediately after transfection. (Figure 2) shoes an inhibitory effect of expression of glucocorticoids receptor on pit 1 activation. Of $\operatorname{prPrl}(-1960 /+38)$ CAT, pS (-) p (-423/-44)-CAT on transfection into CV-1 cells Schuster et al. (1988). However the effect is seen UN the presence and absence of dexameha - some (10-6M).

This may reflect an excessive over production of (GR) from the expression vector (Figure 3) again shows the effect on prPrl ($1960 /+38)$ - CAT but low induction of pS (-) - (-75/+38)-CAT expression allowed no conclusion to be drawn in the case of $\mathrm{pS} \mathrm{(-)} \mathrm{p} \mathrm{(-}$ 75/+38)-CAT Eljaafry et al. ${ }^{(3)}$.

\section{MATERIAL \& METHODS}

A small set of 3, -deletion mutants of the rat prolactin promoter were generated using the exonuclease Bal 31. They had 5, -border at 423 (transcription start site +1 ).

DNA sequencing analysis showed the deletion mutant to have 3, -borders at $(-44,-120,--190,-230,-960$ and -1960) for characterization, they were introduced into pRSV - Grand pCMV_pit1 (glucocorticoids receptor) expression vectors. The resulting plasmids were then transfected into $\mathrm{CV}-1$ cells. 
The transcriptional activity of the prolactin promoter fragments was assayed by measuring the chloramphenicol acetyltransferase (CAT).

\section{RESULTS}

In (Figures 1-3) results of a series of preliminary studies on the effects of glucocorticoids on pitl activated expression from the $\mathrm{rPrl}$ promoter fragments is shown. Comper et al. (2) and Adler et al. ${ }^{(1)}$ had shown that glucocorticoids suppress transcription from mammalian prolactin promoters.

In these studies glucocorticoids receptor (GR) deficient CV-1 cells were used and the (GR) was expressed from an expression vector Parker et al. ${ }^{(5)}$.

However, in the case of prolactin promoter fragments (eg, 1960/+ 38, -44/ -423, -190/-423 and - 75/+ 38) decreased in pitl induced DAT gene expression was seen when the (GR) was expressed but it was evident even in the absence of glucocorticoids. Maniaatis et al. ${ }^{(3)}$. Whether this reflects the high level of (GR) expression. 


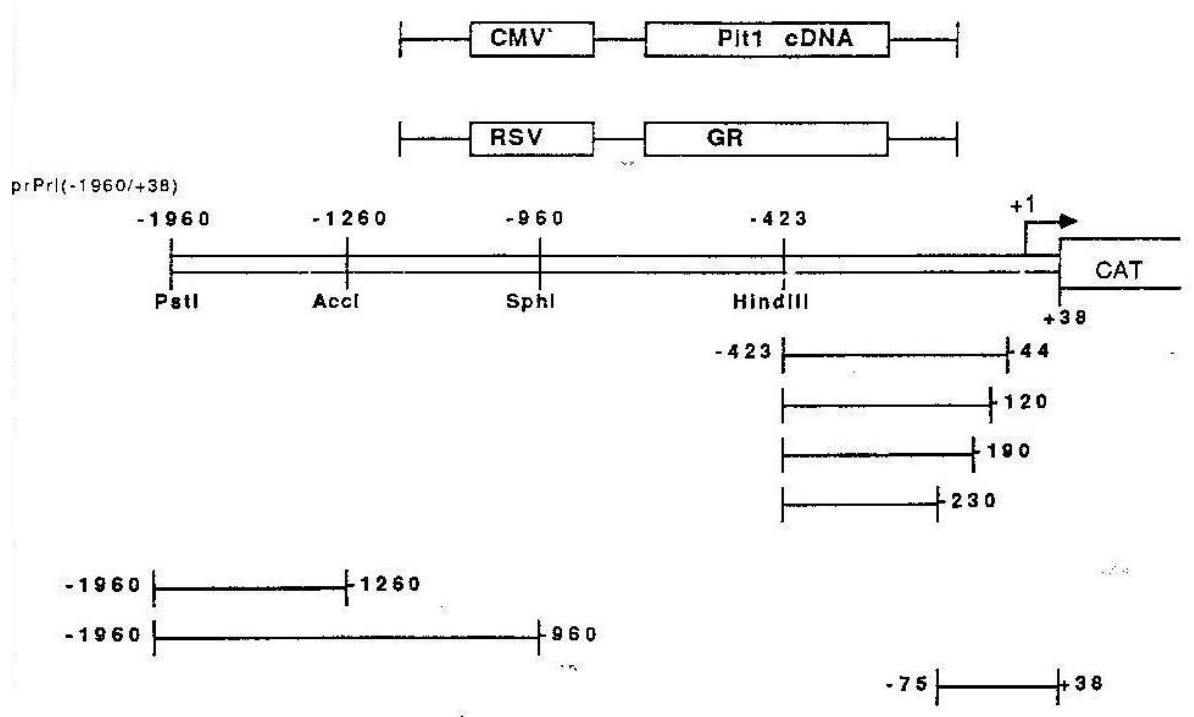

Fig : : Schematic representation of the PCMV-Pitf and pRSV-GR (giucocorticoid receptor) expression vectors and the reporter plasmid prPrl(-1960/+38)-CAT and the $\mathrm{PPr}$ promoter fragments tested in $\operatorname{pS}(-) \mathrm{P}(\Delta)$-CAT constructs. 
A $\quad \mathrm{CV}-1$

$\begin{array}{llllllllll}C & 1 & 2 & 3 & 4 & 5 & 6 & 7 & 8 & 9\end{array}$

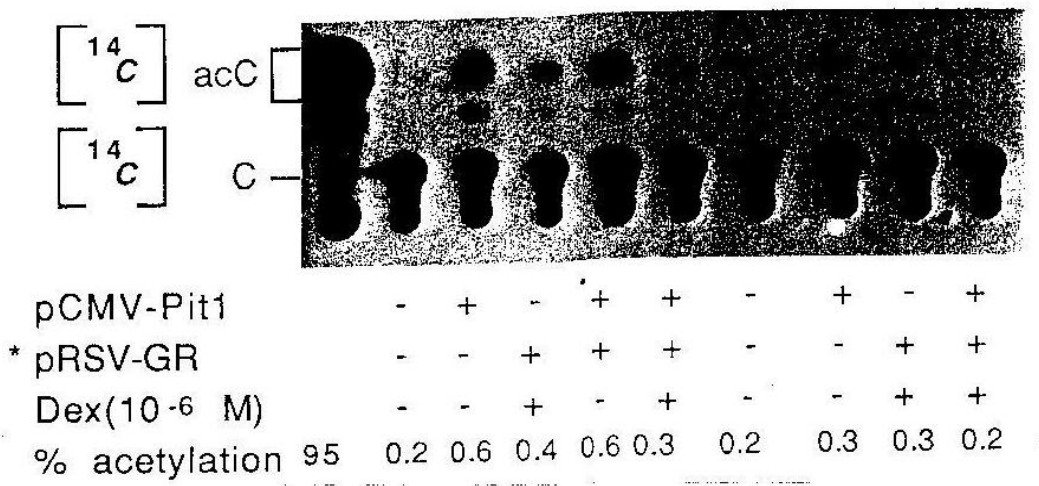

B.

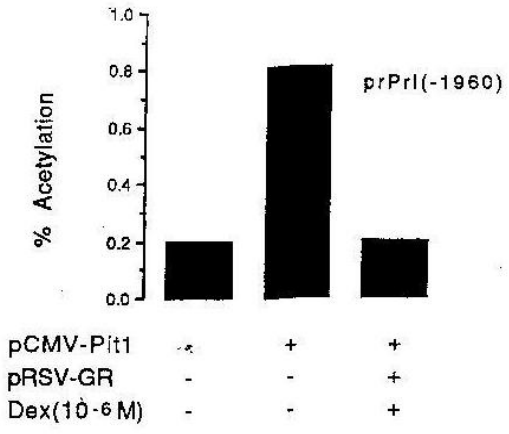

FIg3e: Effect of glucocorticoids on Pity transcription activity from the 5'-rPrl-promoter deletion fragments after co-transfeciton with pCMV.Pit1 into non pituitary celis. A). Shown is an autoradiograph of a representative CAT enzyme assay indicating the effect on Pit1 activity on co-transfection into $C V-1$ cells with pRSV-GR in the presence and absence of dexamethasone (10.6 M) : Lanes1-5: prPrl( $-1960 /+38)$-CAT, lanes 6-9: prPrl(-75/+38)-CAT, IaneC: represents where pure CAT enzyme was incubated in place of cell extract. Values for CAT activity are presented as $\%$ acetylation of $[14 \mathrm{C}]$-chioramphenicol.

B). Shown is the mean CAT activity from 3 independent expriments presented as $\%$ acetylation of $[14 \mathrm{C}]$-chloramphenicol observed in $\mathrm{CV}-1$ cells co-transfected with prPrl(-1960/+38)-CAT and pCMV-Pit 1 in the presence and absence of pRSV-GR and dexamethason (10-6 M).

* Glucocorticoid-Receptor expression vector. 
CV-1

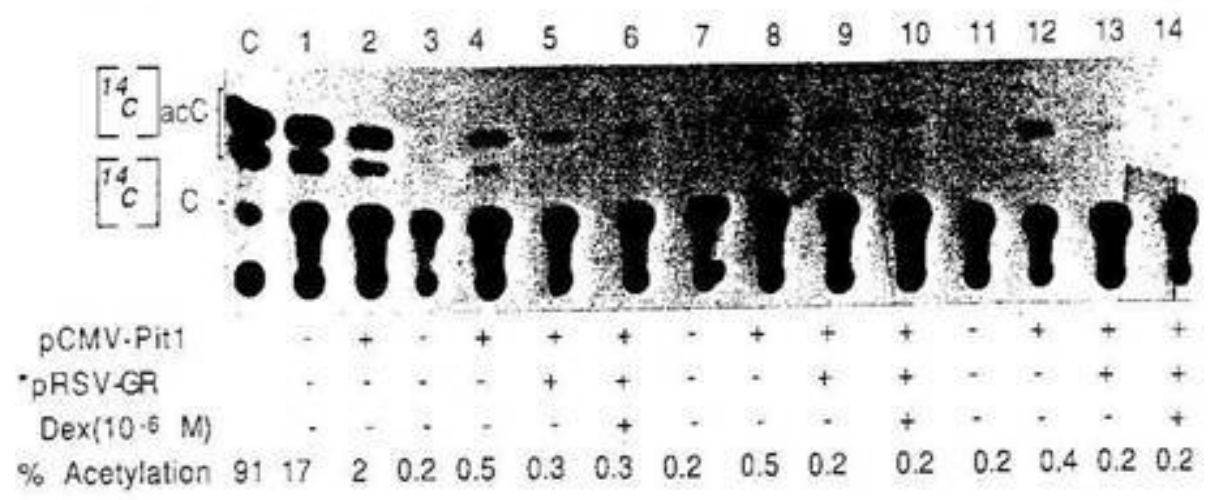

Fig 2. Effect of glucocorticoids on Pit1 transcription from the $3^{\prime} \cdot$-Pri-promoter deletion fiagments after co-transfection with pCMV-Pit1 Into non pituitary cells.

Shown is an autoradiograph of a representative CAT enzyme assay indicating the effect on Pit1 activity on co-transfection into CV-1 cells with PRSV-GR in the presence and absence of dexamethasone $(10.6 \mathrm{M})$ : Lanes1,2: pSV2-CAT, lanes3-6: prPrl(-1966/+38)-CAT, lanes7-10: pS $(-)$ P $(-423 /-44)$-CAT, lanes 11-14:pS $(-) P(-423 /-190)-C A T$, laneC: represents where pure CAT enzyme was incubated in place of cell extract. Values for CAT activity are presented as \% acetylation of $[14 \mathrm{C}]$-chloramphenicol.

Glucocorticoid-Fleceptor expression vector. 


\section{DISCUSSION}

In (Figures 1-3) results of a series of preliminaey studies on the effects of glucocorticoids on pitl activated expression from the $\mathrm{rPrl}$ promoter fragments is shown. Comper et al. ${ }^{(2)}$ and Adler et al. ${ }^{(1)}$ had shown that glucocorticoids suppress transcription from mammalian prolactin promoters. In these studies glucocorticoids receptor (GR) deficient CV-1 cells were used and the (GR) was expressed from an expression vector Parker et al. ${ }^{(5)}$.

However, in the case of prolactin promoter fragments (eg, 1960/+ 38, -44/ $-423,-190 /-423$ and $-75 /+38$ ) adcreased in pitl induced DAT gene expression was seen when the (GR) was expressed but it was evident even in the absence of glucocorticoids. Maniaatis et al. ${ }^{(3)}$. Whether this reflects the high level of (GR) expression.

\section{REFERENCES}

1- Adler, S., Waterman, M.L., He, L. and Rosenfeld, M.G (1988): Steroid receptor mediated inhibition of rat prolactin gene ex pression does not require the receptor DNA- binding domain. Cell, 52,685-695

2- Camper, S.A., Yao, Y.S.A., Rottman, F.M. (1985): Hormonal regulation of the bovine prolactin. Promoter tumor cells .J.Bio. Chem.260, 12246-12251

3- Eljaafri, S., and F. Martin (1991): construction of rPrl promoter. Bioch.soc.Trans

4- Maniatis, T., Goodboura, S. and Fisher, J.K. (1987): Regulation of inducible and tissue- specific gene expression. Science 235, 1237-1244.

5- Parker, A. and Stark, F.R.(1994): Simulation of SV40 transcription sensitive analysis of the RNA species present early in 
infections by viral or viral DNA.J.Virol31,360-369 6 Treacy,M.N.Schuster, W.A. and Martin,F.(1988): Tissue specific trans - acting factor interaction proximal rat prolactin gene promoter sequences . EMBOJ.7, 1721-1733. 